\title{
Synthesis of 1,3-Bis(trimethylcyclam) and 1,3-Bis(trimethylcyclen) Substituted Benzenes
}

\author{
Alexei D. Averin, ${ }^{a}{ }^{@}$ Anton V. Shukhaev, ${ }^{a}{ }^{\text {Alexei K. Buryak, }}{ }^{\text {b }}$ Franck Denat, $^{\mathrm{c}}$ \\ Roger Guilard, ${ }^{\mathrm{c}}$ and Irina P. Beletskaya ${ }^{\mathrm{a}}$ \\ ${ }^{a}$ Lomonosov Moscow State University, Department of Chemistry, Leninskie Gory, Moscow, 119991 Russia \\ ${ }^{\mathrm{b}}$ A.N. Frumkin Institute of Physical and Electrochemistry, 31 Leninskii prosp., Moscow, 119991, Russia \\ 'Institut de Chimie Moléculaire de l'Universite de Bourgogne (ICMUB-LIMRES) UMR CNRS 5260, 9 av. Alain Savary, \\ 21078 Dijon, France \\ @Corresponding authorE-mail: averin@org.chem.msu.ru
}

\begin{abstract}
Pd-catalyzed amination of 1,3-dibromobenzene with $N, N^{\prime}, N^{\prime \prime}$-trimethylcyclam and $N, N^{\prime}, N^{\prime \prime}$-trimethylcyclen provided corresponding 1,3-bis(tetraazamacrocyclic) derivatives of benzene in 25-32\% yields. The dependence of the products yields on the phosphine ligand applied (BINAP, DavePHOS) as well as on the stoichiometry of starting compounds was established. Scope and limitations for the synthesis of $N$-phenyl and N-(3-bromophenyl) derivatives of trimethylcyclam and trimethylcyclen were demonstrated.
\end{abstract}

Keywords: Tetraazamacrocycles, amination, Pd catalysis, aryl halides.

\section{Introduction}

Tetraazamacrocyclic compounds, mainly cyclams and cyclens, are of major importance due to their unique properties for selective binding of metal ions. ${ }^{[1,2]}$ Numerous derivatives of these molecules find application as highly efficient sequestrating agents, ${ }^{[3,4]}$ sensors, ${ }^{[5,6]}$ catalysts, ${ }^{[7]}$ and are used in biochemistry ${ }^{[8,9]}$ or medicine. ${ }^{[10,11]}$ Moreover, bis(polyazamacrocycles) attract significant interest due to their abilities to form binuclear complexes. ${ }^{[12,13]}$ Over the last decades, the use of saturated bismacrocyclic ligands instead of bisporphyrin compounds has been studied because of their easier synthesis. ${ }^{[14,15]}$ They contain two polyazamacrocycles which are linked, either through aliphatic (or aromatic) spacers bonded to nitrogen atoms or through two covalently bonded carbon atoms. ${ }^{[16-23]}$ The synthesis of a variety of bismacrocycles bound through aryl spacers was described by the authors. ${ }^{[12]}$ However, in all cited syntheses only aliphatic or benzyl-type linkers have been used to prepare these models; direct bonding of two polyazamacrocycles to an aryl spacer could hardly be achieved with known synthetic procedures, and this fact strictly limited any progress in this area. We proposed the application of the Pd-catalyzed amination of aryl halides for this purpose and showed the possibility of the synthesis of 1,8-bis(cyclam) substituted anthracene. ${ }^{[24]}$ In the present paper we describe the Pd-mediated amination of 1,3-dibromobenzene with $N, N^{\prime}, N^{\prime \prime}$-trimethylcyclam and $N, N^{\prime} N^{\prime \prime}$-trimethylcyclen for the synthesis of new bismacrocycles, $N$-phenyl and $N$-(3bromophenyl) derivatives of tetraazamacrocycles.

\section{Experimental}

NMR spectra were registered using Bruker Avance 400 spectrometer, MALDI-TOF spectra were obtained with Bruker
Ultraflex spectrometer using 1,8,9-trihydroxyanthracene as matrix 1,3-Dibromobenzene, 2,2'-bis(diphenylphosphino)-1,1'-binaphtyl (BINAP), 2-dimethylamino-2'-dicyclohexylphosphinobiphenyl (DavePHOS) and other phosphine ligands, benzyl bromide, formic acid, formalin, acetic acid, sodium tert-butylate were purchased from Aldrich and Acros and used without further purification; cyclam and $N$-benzylcyclen were provided by Chemathec Co, Pd dibenzylydene acetonate $\left(\mathrm{Pd}(\mathrm{dba})_{2}\right)$ was synthesized according to the method described. ${ }^{[25]}$ Dioxane was distilled over $\mathrm{NaOH}$ followed by the distillation over sodium in argon, dichloromethane and methanol were distilled. Synthesis of $N, N^{\prime}, N^{\prime \prime}$-trimethylcyclam 1 was carried out using a three-step procedure from cyclam by its $\mathrm{N}$-benzylation with benzyl bromide, followed by methylation with a mixture of formalin and formic acid, and reduction of $\mathrm{N}$-benzyl$N^{\prime}, N^{\prime \prime}, N^{\prime \prime \prime}$-trimethylcyclam with hydrogen catalyzed by Pd on carbon. ${ }^{[26]} N, N^{\prime}, N^{\prime \prime}$-trimethylcyclen $\mathbf{4}$ was obtained according to a similar procedure which was found to be easier than an alternative one described in literature. ${ }^{[27]}$

1-Benzyl-4,7,10-trimethyl-1,4,7,10-tetraazacyclododecane, 3. $\mathrm{N}$-benzylcyclen 2 (5 g, $0.019 \mathrm{~mol}$ ) was mixed with $99 \%$ formic acid $(3.5 \mathrm{ml}, 0.091 \mathrm{~mol}), 37 \%$ formalin $(4.7 \mathrm{~g}, 0.058 \mathrm{~mol})$ and 0.45 $\mathrm{ml}$ water. The mixture was refluxed for $24 \mathrm{~h}$, cooled to ambient temperature, the excess of formic acid and formaldehyde was evaporated in vacuo, and the residue was dissolved in water (40 $\mathrm{ml})$. The solution of $\mathrm{KOH}(4.5 \mathrm{~g})$ in $40 \mathrm{ml}$ water was added to make $\mathrm{p} H 10$, the resulted solution was extracted with dichloromethane $(2 \times 75 \mathrm{ml})$, organic phases were combined and dried over $\mathrm{MgSO}_{4}$. Dichloromethane was evaporated in vacuo, and the product 3 was obtained as viscous oil. Yield $4.92 \mathrm{~g}(85 \%) . \mathrm{m} / z$ (MALDI-TOF) $305.4\left[(\mathrm{M}+\mathrm{H})^{+}\right] .{ }^{1} \mathrm{H}$ NMR $\left(\mathrm{CDCl}_{3}, 297 \mathrm{~K}\right) \delta_{\mathrm{H}} \mathrm{ppm}: 2.19(6 \mathrm{H}, \mathrm{s}$, $2 \times \mathrm{Me}), 2.28(3 \mathrm{H}, \mathrm{s}, \mathrm{Me}), 2.49-2.60\left(12 \mathrm{H}, \mathrm{m}, \mathrm{CH}_{2} \mathrm{~N}\right), 2.66(4 \mathrm{H}$, $\left.\mathrm{t},{ }^{3} \mathrm{~J}=5.3 \mathrm{~Hz}, \mathrm{CH}_{2} \mathrm{~N}\right), 3.55\left(2 \mathrm{H}, \mathrm{s}, \mathrm{NCH}_{2} \mathrm{Ph}\right), 7.21\left(1 \mathrm{H}, \mathrm{t},{ }^{3} \mathrm{~J}=7.3\right.$ $\mathrm{Hz}, p-\mathrm{Ph}), 7.29\left(2 \mathrm{H}, \mathrm{t},{ }^{3} J=7.4 \mathrm{~Hz}, m-\mathrm{Ph}\right), 7.33\left(2 \mathrm{H}, \mathrm{d},{ }^{3} J=7.4 \mathrm{~Hz}\right.$, $o$-Ph). ${ }^{13} \mathrm{C} \mathrm{NMR}\left(\mathrm{CDCl}_{3}, 297 \mathrm{~K}\right) \delta_{\mathrm{c}} \mathrm{ppm}: 44.5(1 \mathrm{C}), 45.4(2 \mathrm{C}), 53.0$ (2C), 56.0 (1C), 56.2 (2C), 56.6 (2C), 61.1 (2C), 127.1 (1C), 128.5 (2C), 129.4 (2C), 140.2 (1C).

1,4,7-Trimethyl-1,4,7,10-tetraazacyclododecane, 4. Benzyltrimethylcyclen 3 (4.92 g, $0.016 \mathrm{~mol}$ ) was mixed with 10\% Pd on 
carbon $(0.5 \mathrm{~g})$ in acetic acid $(200 \mathrm{ml})$. The mixture was saturated with hydrogen at atmospheric pressure and under stirring for $2 \mathrm{~h}$. Then the catalyst was filtered off, acetic acid was evaporated in vacuo, and $\mathrm{KOH}$ solution in water was added to make $\mathrm{pH}$ 9. The product was extracted with dichloromethane $(3 \times 100 \mathrm{ml})$. Combined organic phases were dried over $\mathrm{MgSO}_{4}$. Dichloromethane was evaporated in vacuo, and the product $\mathbf{4}$ was obtained as viscous oil. Yield $3.25 \mathrm{~g}(95 \%) . \mathrm{m} / z$ (MALDI-TOF) $214.7\left[\mathrm{M}^{+}\right]$. ${ }^{1} \mathrm{H}$ NMR $\left(\mathrm{CDCl}_{3}, 297 \mathrm{~K}\right) \delta_{\mathrm{H}}$ ppm: 2.15 (3H, s, Me), 2.34 (6H, s, 2 x Me), 2.47 $\left(8 \mathrm{H}\right.$, br s, $\left.\mathrm{CH}_{2} \mathrm{~N}\right), 2.62\left(4 \mathrm{H}\right.$, br s, $\left.\mathrm{CH}_{2} \mathrm{~N}\right), 2.73\left(4 \mathrm{H}\right.$, br s, $\left.\mathrm{CH}_{2} \mathrm{~N}\right) \cdot{ }^{13} \mathrm{C}$ NMR $\left(\mathrm{CDCl}_{3}, 297 \mathrm{~K}\right) \delta_{\mathrm{C}}$ ppm: 39.5 (1C), 45.1 (2C), 46.9 (2C), 53.0 (2C), 53.4 (2C), 55.0 (2C)

General procedure for the Pd-catalyzed arylation of $N, N^{\prime}, N^{\prime \prime}-$ trimethylcyclam 1 and $N, N^{\prime}, N^{\prime \prime}$-triemethylcyclen 4.

A two-necked flask equipped with a condenser and magnetic stirrer, flushed with dry argon, was charged with 1,3-dibromobenzene (0.2-2 $\mathrm{mmol}), \quad \mathrm{Pd}(\mathrm{dba})_{2} \quad(4-16 \mathrm{~mol} \%)$, phosphine ligand ( $8-16 \mathrm{~mol} \%$ ), abs. dioxane $(2.5-5 \mathrm{ml})$, the mixture was stirred for $2 \mathrm{~min}$, then tetraazamacrocycle 1 or $4(0.2-1 \mathrm{mmol})$ was added, followed by sodium tert-butylate (1.5 equiv. per bromine atom), and the reaction mixture was refluxed for 24-30 h. After cooling to ambient temperature, the solution was filtered off, evaporated in vacuo, and the residue was chromatographed on silica gel using a sequence of eluents: $\mathrm{CH}_{2} \mathrm{Cl}_{2}, \mathrm{CH}_{2} \mathrm{Cl}_{2}-\mathrm{MeOH}$ 20:1-3:1, $\mathrm{CH}_{2} \mathrm{Cl}_{2}-\mathrm{MeOH}-\mathrm{NH}_{3}$ aq 100:20:1-10:4:1.

1-(3-Bromophenyl)-4,8,11-trimethyl-1,4,8,11-tetraazacyclotetradecane, 5. According to the method described, compound 5 was obtained from 1,3-dibromobenzene $(118 \mathrm{mg}, 0.5 \mathrm{mmol})$, trimethycyclam 1 (60 mg, $0.25 \mathrm{mmol})$, in the presence of $\mathrm{Pd}(\mathrm{dba})_{2}$ (12 mg, $8 \mathrm{~mol} \%$ ), BINAP (14 mg, $9 \mathrm{~mol} \%$ ), sodium tert-butylate (36 mg, $0.38 \mathrm{mmol})$ in dioxane $(2.5 \mathrm{ml}, 0.1 \mathrm{M})$. Eluent: $\mathrm{CH}_{2} \mathrm{Cl}_{2}$ $\mathrm{MeOH}-\mathrm{NH}_{3}$ aq 100:20:2. Yield $26 \mathrm{mg}$ (26\%). $\mathrm{m} / z$ (MALDI-TOF) $397.0\left[(\mathrm{M}+\mathrm{H})^{+}\right] .{ }^{1} \mathrm{H} \mathrm{NMR}\left(\mathrm{CDCl}_{3}, 297 \mathrm{~K}\right) \delta_{\mathrm{H}} \mathrm{ppm}: 1.79(2 \mathrm{H}$, quintet, $\left.{ }^{3} \mathrm{~J}=5.7 \mathrm{~Hz}, \mathrm{CCH}_{2} \mathrm{C}\right), 1.90\left(2 \mathrm{H}\right.$, quintet, $\left.{ }^{3} \mathrm{~J}=6.1 \mathrm{~Hz}, \mathrm{CCH}_{2} \mathrm{C}\right), 2.31$ $(3 \mathrm{H}, \mathrm{s}, \mathrm{Me}), 2.33(3 \mathrm{H}, \mathrm{s}, \mathrm{Me}), 2.43(3 \mathrm{H}, \mathrm{s}, \mathrm{Me}), 2.55(2 \mathrm{H}, \mathrm{br} \mathrm{s}$, $\left.\mathrm{CH}_{2} \mathrm{~N}\right), 2.60\left(4 \mathrm{H}, \mathrm{t},{ }^{3} \mathrm{~J}=5.6 \mathrm{~Hz}, \mathrm{CH}_{2} \mathrm{~N}\right), 2.73\left(4 \mathrm{H}\right.$, br s, $\left.\mathrm{CH}_{2} \mathrm{~N}\right), 2.86$ $\left(2 \mathrm{H}\right.$, br s, $\left.\mathrm{CH}_{2} \mathrm{~N}\right), 3.45\left(2 \mathrm{H}, \mathrm{t},{ }^{3} \mathrm{~J}=6.6 \mathrm{~Hz}, \mathrm{CH}_{2} \mathrm{NPh}\right), 3.47(2 \mathrm{H}, \mathrm{t}$, $\left.{ }^{3} J=5.8 \mathrm{~Hz}, \mathrm{CH}_{2} \mathrm{NPh}\right), 6.59\left(1 \mathrm{H}, \mathrm{d},{ }^{3} J=8.1 \mathrm{~Hz}, \mathrm{H}^{6}-\mathrm{Ph}\right), 6.75(1 \mathrm{H}$, $\left.\mathrm{s}, \mathrm{H}^{2}-\mathrm{Ph}\right), 6.76\left(1 \mathrm{H}, \mathrm{d},{ }^{3} \mathrm{~J}=7.8 \mathrm{~Hz}, \mathrm{H}^{4}-\mathrm{Ph}\right), 6.99\left(1 \mathrm{H}, \mathrm{t},{ }^{3} \mathrm{~J}=7.9 \mathrm{~Hz}\right.$, $\left.\mathrm{H}^{5}-\mathrm{Ph}\right) .{ }^{13} \mathrm{C} \mathrm{NMR}\left(\mathrm{CDCl}_{3}, 297 \mathrm{~K}\right) \delta_{\mathrm{C}} \mathrm{ppm}: 23.4,24.5,42.1,42.3$, 43.7, 48.0, 49.7, 53.6, 53.9, 54.3, 54.5, 54.9, 55.5, 110.9, 115.0, 118.9, $123.5,130.5,149.6$.

1,4,8-Trimethyl-11-phenyl-1,4,8,11-tetraazacyclotetradecane, 6. Obtained as the second product in the same synthesis. Eluent: $\mathrm{CH}_{2} \mathrm{Cl}_{2}-\mathrm{MeOH}-\mathrm{NH}_{3}$ aq. 100:20:3. Yield $14 \mathrm{mg}$ (18\%). $\mathrm{m} / \mathrm{z}$ (MALDI-TOF) $319.3\left[(\mathrm{M}+\mathrm{H})^{+}\right]$. ${ }^{1} \mathrm{H}$ NMR $\left(\mathrm{CDCl}_{3}, 297 \mathrm{~K}\right) \delta_{\mathrm{H}} \mathrm{ppm}$ : $1.74\left(2 \mathrm{H}\right.$, quintet, $\left.{ }^{3} J=6.4 \mathrm{~Hz}, \mathrm{CCH}_{2} \mathrm{C}\right), 1.83\left(2 \mathrm{H}\right.$, quintet, ${ }^{3} J=6.3$ $\left.\mathrm{Hz}, \mathrm{CCH}_{2} \mathrm{C}\right), 2.31$ (3H, s, Me), 2.34 (3H, s, Me), 2.36 (3H, s, Me), $2.56\left(2 \mathrm{H}\right.$, br s, $\left.\mathrm{CH}_{2} \mathrm{~N}\right), 2.63\left(4 \mathrm{H}, \mathrm{t},{ }^{3} \mathrm{~J}=5.9 \mathrm{~Hz}, \mathrm{CH}_{2} \mathrm{~N}\right), 2.67(4 \mathrm{H}, \mathrm{br}$ $\left.\mathrm{s}, \mathrm{CH}_{2} \mathrm{~N}\right), 2.74\left(2 \mathrm{H}, \mathrm{br} \mathrm{s}, \mathrm{CH}_{2} \mathrm{~N}\right), 3.44\left(2 \mathrm{H}, \mathrm{t},{ }^{3} \mathrm{~J}=6.6 \mathrm{~Hz}, \mathrm{CH}_{2} \mathrm{NPh}\right)$, $3.50\left(2 \mathrm{H}, \mathrm{t},{ }^{3} J=6.1 \mathrm{~Hz}, \mathrm{CH}_{2} \mathrm{NPh}\right), 6.67\left(1 \mathrm{H}, \mathrm{t},{ }^{3} J=7.4 \mathrm{~Hz}, p-\mathrm{Ph}\right)$, $6.68\left(2 \mathrm{H}, \mathrm{d},{ }^{3} \mathrm{~J}=8.3 \mathrm{~Hz}, o-\mathrm{Ph}\right), 7.20\left(2 \mathrm{H}, \mathrm{dd},{ }^{3} \mathrm{~J}=8.9 \mathrm{~Hz},{ }^{3} \mathrm{~J}=7.1\right.$ $\mathrm{Hz}, m-\mathrm{Ph}) .{ }^{13} \mathrm{C} \mathrm{NMR}\left(\mathrm{CDCl}_{3}, 297 \mathrm{~K}\right) \delta_{\mathrm{C}} \mathrm{ppm}: 24.1,24.4,42.3,42.8$, 44.0, 47.7, 49.4, 53.7, 53.9, 54.3, 54.9, 55.0, 55.2, 111.9 (2C), 115.7, $129.3(2 \mathrm{C}), 148.3$.
1,3-Bis(4,8,11-trimethyl-1,4,8,11-tetraazacyclotetradecan-1yl)benzene, 7. According to the method described, bismacrocyclic compound 7 was obtained from 1,3-dibromobenzene (472 mg, 2 $\mathrm{mmol})$, trimethylcyclam $1(242 \mathrm{mg}, 1 \mathrm{mmol})$, in the presence of Pd(dba) $)_{2}$ (46 mg, $8 \mathrm{~mol} \%$ ), DavePHOS (31 mg, $8 \mathrm{~mol} \%$ ), sodium tert-butylate $(288 \mathrm{mg}, 3 \mathrm{mmol})$ in dioxane $(5 \mathrm{ml}, 0.2 \mathrm{M})$. Eluent: $\mathrm{CH}_{2} \mathrm{Cl}_{2}-\mathrm{MeOH}-\mathrm{NH}_{3}$ aq. 100:20:2, 100:20:3. Yield $70 \mathrm{mg}$ (25\%). $\mathrm{m} / z$ (MALDI-TOF) $559.5\left[(\mathrm{M}+\mathrm{H})^{+}\right] .{ }^{1} \mathrm{H}$ NMR $\left(\mathrm{CDCl}_{3}, 297 \mathrm{~K}\right) \delta_{\mathrm{H}}$ ppm: $1.60\left(4 \mathrm{H}\right.$, quintet, $\left.{ }^{3} \mathrm{~J}=5.8 \mathrm{~Hz}, \mathrm{CCH}_{2} \mathrm{C}\right), 1.76\left(4 \mathrm{H}\right.$, quintet, ${ }^{3} \mathrm{~J}$ $\left.=5.6 \mathrm{~Hz}, \mathrm{CCH}_{2} \mathrm{C}\right), 2.19(6 \mathrm{H}, \mathrm{s}, 2 \mathrm{x} \mathrm{Me}), 2.23(6 \mathrm{H}, \mathrm{s}, 2 \mathrm{x} \mathrm{Me}), 2.27$ $(6 \mathrm{H}, \mathrm{s}, 2 \mathrm{x} \mathrm{Me}), 2.37\left(4 \mathrm{H}, \mathrm{t},{ }^{3} \mathrm{~J}=5.6 \mathrm{~Hz}, \mathrm{CH}_{2} \mathrm{~N}\right), 2.43-2.57(20 \mathrm{H}, \mathrm{m}$, $\left.\mathrm{CH}_{2} \mathrm{~N}\right), 3.43\left(4 \mathrm{H}, \mathrm{t},{ }^{3} \mathrm{~J}=6.5 \mathrm{~Hz}, \mathrm{CH}_{2} \mathrm{NPh}\right), 3.46\left(4 \mathrm{H}, \mathrm{t},{ }^{3} \mathrm{~J}=6.8 \mathrm{~Hz}\right.$, $\left.\mathrm{CH}_{2} \mathrm{NPh}\right), 5.90\left(1 \mathrm{H}, \mathrm{s}, \mathrm{H}^{2}-\mathrm{Ph}\right), 5.98\left(2 \mathrm{H}, \mathrm{dd},{ }^{3} \mathrm{~J}=8.3 \mathrm{~Hz},{ }^{4} \mathrm{~J}=1.8\right.$ $\left.\mathrm{Hz}, \mathrm{H}^{4}, \mathrm{H}^{6}-\mathrm{Ph}\right), 6.99\left(1 \mathrm{H}, \mathrm{t},{ }^{3} J=8.2 \mathrm{~Hz}, \mathrm{H}^{5}-\mathrm{Ph}\right) .{ }^{13} \mathrm{C} \mathrm{NMR}\left(\mathrm{CDCl}_{3}\right.$, $297 \mathrm{~K}) \delta_{\mathrm{C}}$ ppm: $24.7(2 \mathrm{C}), 25.1(2 \mathrm{C}), 42.3(2 \mathrm{C}), 43.2(2 \mathrm{C}), 44.4$ (2C), 47.5 (2C), 49.5 (2C), 53.7 (2C), 53.9 (2C), 54.7 (2C), 55.1 (4C), $55.4(2 \mathrm{C}), 94.6(1 \mathrm{C}), 99.8(2 \mathrm{C}), 129.8(1 \mathrm{C}), 149.5(2 \mathrm{C})$.

1-(3-Bromophenyl)-4,7,10-trimethyl-1,4,7,10-tetraazacyclododecane, 8. According to the method described, compound 8 was obtained from 1,3-dibromobenzene $(118 \mathrm{mg}, 0.5 \mathrm{mmol})$, trimethycyclen 4 (107 mg, $0.5 \mathrm{mmol})$, in the presence of $\operatorname{Pd}(\mathrm{dba})_{2}$ ( $23 \mathrm{mg}, 8 \mathrm{~mol} \%$ ), BINAP (28 mg, $9 \mathrm{~mol} \%$ ), sodium tert-butylate (72 $\mathrm{mg}, 0.75 \mathrm{mmol})$ in dioxane $(5 \mathrm{ml}, 0.1 \mathrm{M})$. Eluent: $\mathrm{CH}_{2} \mathrm{Cl}_{2}-\mathrm{MeOH}$ 3:1. Yield $23 \mathrm{mg}(13 \%) . \mathrm{m} / z$ (MALDI-TOF) $369.0\left[(\mathrm{M}+\mathrm{H})^{+}\right] .{ }^{1} \mathrm{H}$ NMR $\left(\mathrm{CDCl}_{3}, 297 \mathrm{~K}\right) \delta_{\mathrm{H}}$ ppm: $2.22(3 \mathrm{H}, \mathrm{s}, \mathrm{Me}), 2.37(6 \mathrm{H}, \mathrm{s}, 2 \mathrm{x}$ Me), $2.49\left(8 \mathrm{H}\right.$, br s, $\left.\mathrm{CH}_{2} \mathrm{~N}\right), 2.80\left(4 \mathrm{H}\right.$, br s, $\left.\mathrm{CH}_{2} \mathrm{~N}\right), 3.45(4 \mathrm{H}$, br s, $\left.\mathrm{CH}_{2} \mathrm{NPh}\right), 6.53\left(1 \mathrm{H}, \mathrm{d},{ }^{3} J=7.3 \mathrm{~Hz}, \mathrm{H}^{6}-\mathrm{Ph}\right), 6.70\left(1 \mathrm{H}, \mathrm{s}, \mathrm{H}^{2}-\mathrm{Ph}\right), 6.88$ $\left(1 \mathrm{H}, \mathrm{d},{ }^{3} J=7.7 \mathrm{~Hz}, \mathrm{H}^{4}-\mathrm{Ph}\right), 7.08\left(1 \mathrm{H}, \mathrm{t},{ }^{3} J=7.5 \mathrm{~Hz}, \mathrm{H}^{5}-\mathrm{Ph}\right)$.

1,4,7-Trimethyl-10-phenyl-1,4,7,10-tetraazacyclododecane, 9. Obtained as the second product in the same synthesis. Eluent: $\mathrm{CH}_{2} \mathrm{Cl}_{2}-\mathrm{MeOH}$ 3:1. Yield $19 \mathrm{mg}(13 \%) . \mathrm{m} / z$ (MALDI-TOF) 291.0 $\left[(\mathrm{M}+\mathrm{H})^{+}\right] .{ }^{1} \mathrm{H} \mathrm{NMR}\left(\mathrm{CDCl}_{3}, 297 \mathrm{~K}\right) \delta_{\mathrm{H}} \mathrm{ppm}: 2.16(3 \mathrm{H}, \mathrm{s}, \mathrm{Me}), 2.28$ $(6 \mathrm{H}, \mathrm{s}, 2 \mathrm{x} \mathrm{Me}), 2.49\left(8 \mathrm{H}\right.$, br s, $\left.\mathrm{CH}_{2} \mathrm{~N}\right), 2.66\left(4 \mathrm{H}, \mathrm{br} \mathrm{s}, \mathrm{CH}_{2} \mathrm{~N}\right), 3.45$ (4H, br s, $\left.\mathrm{CH}_{2} \mathrm{NPh}\right), 6.63\left(2 \mathrm{H}, \mathrm{d},{ }^{3} J=8.4 \mathrm{~Hz}, o-\mathrm{Ph}\right), 6.78\left(1 \mathrm{H}, \mathrm{t},{ }^{3} \mathrm{~J}\right.$ $=7.0 \mathrm{~Hz}, p-\mathrm{Ph}), 7.23\left(2 \mathrm{H}, \mathrm{t},{ }^{3} J=7.9 \mathrm{~Hz}, m-\mathrm{Ph}\right)$.

1,3-Bis 4, 7,10-trimethyl-1,4,7,10-tetraazacyclododecan-1yl)benzene, 10. According to the method described, compound 10 was obtained from 1,3-dibromobenzene $(47 \mathrm{mg}, 0.2 \mathrm{mmol}$ ), trimethylcyclen 4 (43 mg, $0.2 \mathrm{mmol})$, in the presence of $\mathrm{Pd}(\mathrm{dba})_{2}$ (9 mg, $8 \mathrm{~mol} \%$ ), DavePHOS (13 mg mg, $16 \mathrm{~mol} \%$ ), sodium tertbutylate $(30 \mathrm{mg}, 0.3 \mathrm{mmol})$ in dioxane $(2 \mathrm{ml}, 0.1 \mathrm{M})$. Eluent: $\mathrm{CH}_{2} \mathrm{Cl}_{2}-\mathrm{MeOH}-\mathrm{NH}_{3}$ aq 10:4:1. Yield $16 \mathrm{mg}(32 \%) . \mathrm{m} / z$ (MALDITOF) $503.3\left[(\mathrm{M}+\mathrm{H})^{+}\right] .{ }^{1} \mathrm{H}$ NMR $\left(\mathrm{CDCl}_{3}, 297 \mathrm{~K}\right) \delta_{\mathrm{H}} \mathrm{ppm}: 2.25(6 \mathrm{H}$, s 2 x Me), $2.34(12 \mathrm{H}, \mathrm{s}, 4 \mathrm{x} \mathrm{Me}), 2.56\left(16 \mathrm{H}, \mathrm{br} \mathrm{s}, \mathrm{CH}_{2} \mathrm{~N}\right), 2.82(8 \mathrm{H}$, br s, $\left.\mathrm{CH}_{2} \mathrm{~N}\right), 3.48\left(8 \mathrm{H}, \mathrm{t},{ }^{3} \mathrm{~J}=5.7 \mathrm{~Hz}, \mathrm{CH}_{2} \mathrm{NPh}\right), 5.94\left(1 \mathrm{H}, \mathrm{s} \mathrm{H}^{2}-\mathrm{Ph}\right)$, $6.01\left(2 \mathrm{H}, \mathrm{d},{ }^{3} J=8.2 \mathrm{~Hz}, \mathrm{H}^{4}, \mathrm{H}^{6}-\mathrm{Ph}\right), 7.01\left(1 \mathrm{H}, \mathrm{t},{ }^{3} J=8.2 \mathrm{~Hz}, \mathrm{H}^{5}-\mathrm{Ph}\right)$. ${ }^{13} \mathrm{C} \mathrm{NMR}\left(\mathrm{CDCl}_{3}, 297 \mathrm{~K}\right) \delta_{\mathrm{C}} \mathrm{ppm}: 43.7(4 \mathrm{C}), 44.2(2 \mathrm{C}), 50.2(4 \mathrm{C})$, 55.0 (4C), 55.7 (4C), 55.8 (4C), 95.8 (1C), 100.8 (2C), 129.7 (1C), $149.4(2 \mathrm{C})$.

\section{Results and Discussion}

The Pd-catalyzed arylation of free cyclen and cyclam is a very difficult task because these cyclic tetraamines readily reduce halogen atoms in aryl halides. Our previous
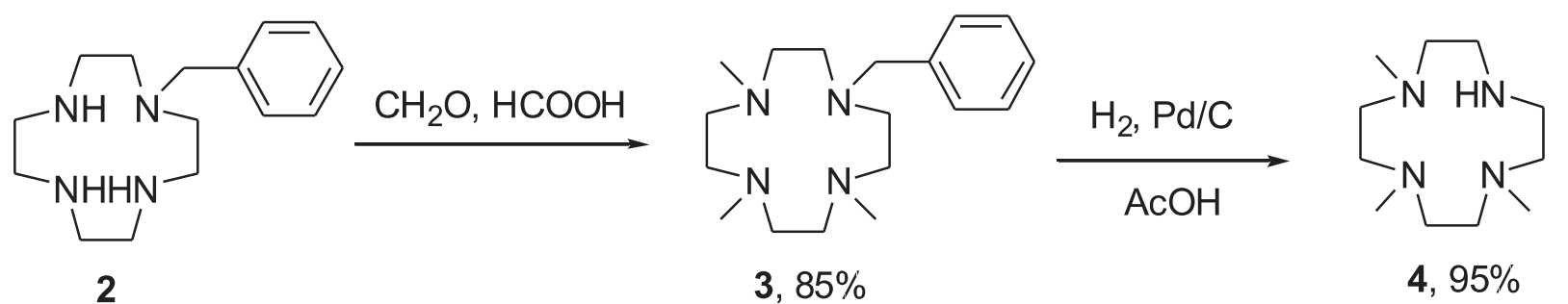

Figure 1. 
<smiles>CN1CCCN(C)CCCN(C)CCC1</smiles>

1<smiles>Brc1cccc(Br)c1</smiles>

$\mathrm{Pd}(\mathrm{dba})_{2} / \mathrm{L}$

tBuONa, dioxane reflux<smiles>CN1CCNCCN(C)CCN(C)CC1</smiles>

4<smiles>CN1CCCN(C)CCN(c2cccc(Br)c2)CCCN(C)CC1</smiles>
5<smiles>CN1CCCN(C)CCN(c2ccccc2)CCC1</smiles>

6<smiles>CN1CCCN(C)CCCN(c2cccc(N3CCCN(C)CCCN(C)CC3)c2)CCN(C)CCC1</smiles>

7<smiles>CN1CCN(c2ccccc2)CCN(C)N(C)CC1</smiles>

9<smiles></smiles>

10

Figure 2.

attempts to carry out such reactions were not encouraging and thus we decided to diminish the number of secondary amino groups active in the reduction process by using $N, N^{\prime}, N^{\prime \prime}$-trimethylsubstituted analogs of cyclen and cyclam. [24] Trimethylcyclam 1 was synthesized from free cyclam by a three-step procedure documented in literature, ${ }^{[26]}$ and the same procedure was used to obtain trimethylcyclen 4 (Figure 1).

We started from $N$-benzylcyclen 2, carried out its exhaustive $N$-methylation with formic acid and formalin to obtain tetrasubstituted cyclen $\mathbf{3}$, and eliminated the benzyl group by the catalytic hydrogenation. As a result, trimethylcyclen 4 was synthesized in overall 80\% yield.

First we tried the catalytic arylation of trimethylcyclam 1. To synthesize desired bis(cyclam) substituted benzene we applied 2 equivalents of trimethylcyclam in the presence of $\mathrm{Pd}(\mathrm{dba})_{2} / \mathrm{BINAP}(8 / 9 \mathrm{~mol} \%$ ) which was well documented to be an universal and the most appropriate catalytic system for amines arylation ${ }^{[28]}$ in general and for the diamination of 1,3-dibromobenzene, in particular. ${ }^{[29]}$ Sodium tert-butylate was used as a base, and the reaction was refluxed for $24 \mathrm{~h}$ in dioxane $(0.1 \mathrm{M})$ (Figure 2).

Under these conditions we obtained the target bismacrocycle 7 in 13\% yield (Table 1, entry 1). We supposed that the change of BINAP for some donor phosphine ligands could improve the diamination process, and tried a series of biphenyl-based monophosphines (Figure 3).

We also checked the ferrocene-based ligand PPFNMe because it proved to be useful in the arylation of free cyclam. ${ }^{[24]}$ However, the most of these ligands did not work at all in the catalytic process, except for 2-dicyclohexylphoshpino2'-dimethylaminobiphenyl (DavePHOS) which was demonstrated to imrpove the amination of aryl chlorides. [30] The use of $16 \mathrm{~mol} \%$ catalyst promoted the diamination process and provided 22\% yield of target bismacrocyclic compound 7 (Table 1, entry 2). We were also interested in the synthesis of monocyclam derivative of bromobenzene 5 in order to study further the possibilities of its catalytic amination with various amines. To synthesize it, we applied 2 equivalents of 1,3-dibromobenzene with $\mathrm{Pd}(\mathrm{dba})_{2} / \mathrm{BINAP}$ $(8 / 9 \mathrm{~mol} \%)$ catalytic system. The target monomacrocyclic compound 5 was isolated in $26 \%$ yield, together with the product of bromine reduction $6(18 \%$, entry 3$)$. In order to increase the product yield, we ran the same reaction in a more concentrated solution $(0.2 \mathrm{M})$, however, in this case the yield of 5 was merely the same ( $24 \%$, entry 4$)$. The use of $\operatorname{Pd}(\mathrm{dba})_{2} /$ DavePHOS $(8 \mathrm{~mol} \%)$ system led to an unexpected result: instead of desired monocyclic derivative 5, bismacrocyclic<smiles>CCOc1ccccc1-c1ccccc1N(C)C</smiles><smiles>O=Pc1ccccc1-c1ccccc1</smiles>

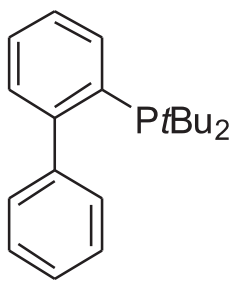<smiles>CCCCCc1ccccc1-c1ccccc1N(C)C</smiles>

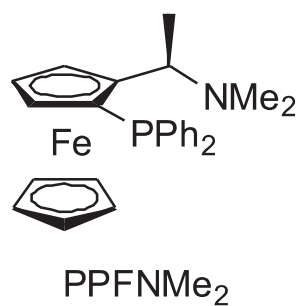

\section{DavePHOS}

Figure 3. 
Table 1. Pd-catalyzed amination of 1,3-dibromobenzene with trimethylcyclam and trimethylcyclen.

\begin{tabular}{ccccccc}
\hline Entry & $\begin{array}{c}\text { Tetraaza- } \\
\text { macrocycle }\end{array}$ & $\begin{array}{c}\text { Ratio 1,3-dibromobenzene/ } \\
\text { tetraazamacrocycle }\end{array}$ & $\begin{array}{c}\text { Concen- } \\
\text { tration, } \mathrm{M}\end{array}$ & Ligand & Pd/L, mol\% & Products yields \\
\hline 1 & $\mathbf{1}$ & $1: 2$ & 0.1 & BINAP & $8 / 9$ & $\mathbf{7}, 13 \%$ \\
2 & $\mathbf{1}$ & $1: 2$ & 0.1 & DavePHOS & $16 / 16$ & $\mathbf{7}, 22 \%$ \\
3 & $\mathbf{1}$ & $2: 1$ & 0.1 & BINAP & $8 / 9$ & $\mathbf{5}, 26 \% ; \mathbf{6}, 18 \%$ \\
4 & $\mathbf{1}$ & $2: 1$ & 0.2 & BINAP & $8 / 9$ & $\mathbf{5}, 24 \%$ \\
5 & $\mathbf{1}$ & $2: 1$ & 0.2 & DavePHOS & $8 / 8$ & $\mathbf{7}, 25 \%$ \\
6 & $\mathbf{4}$ & $1: 1$ & 0.1 & BINAP & $8 / 9$ & $\mathbf{8}, 13 \% ; \mathbf{9}, 13 \%$ \\
7 & $\mathbf{4}$ & $1: 1$ & 0.1 & DavePHOS & $8 / 16$ & $\mathbf{1 0}, 32 \%$ \\
8 & $\mathbf{4}$ & $2: 1$ & 0.2 & BINAP & $8 / 9$ & $\mathbf{1 0}, 20 \%$ \\
9 & $\mathbf{4}$ & $4: 1$ & 0.1 & BINAP & $4 / 9$ & $\mathbf{8}, 12 \% ; \mathbf{9}, 3 \% ; \mathbf{1 0}, 30 \%$ \\
\hline
\end{tabular}

compound 7 was isolated in $25 \%$ yield (entry 5 ). This meant that the application of less catalyst $(8 \mathrm{~mol} \%$ instead of 16 $\mathrm{mol} \%$ ) and, what is much more surprising, the excess of 1,3-dibromobenzene afforded the diamination product in even a better yield (ref. entries 2 and 5).

This unusual effect was more pronounced in the case of trimethylcyclen $\mathbf{4}$ arylation. The reaction of equimolar amounts of trimethylcyclen and 1,3-dibromobenzene catalyzed by $\mathrm{Pd}(\mathrm{dba})_{2} / \mathrm{BINAP} \quad(8 / 9 \mathrm{~mol} \%)$ provided $N$-(3-bromophenyl)trimethylcyclen $\mathbf{8}$ and reduced $N$-phenyltrimethylcyclen 9 in equal yields (13\%, entry 6). The use of DavePHOS ligand under similar conditions gave rise to bismacrocyclic compound $\mathbf{1 0}$ in $32 \%$ yield (entry 7 ). When we changed the ratio of starting compounds taking 2 equivalents of dibromobenzene and $\mathrm{Pd}(\mathrm{dba})_{2} / \mathrm{BINAP}(8 / 9$ mol\%) catalytic system, we also obtained biscyclen derivative $\mathbf{1 0}$ in $20 \%$ yield instead of expected monocyclen compound 8 (entry 8). The most dramatic result was observed when using 4 equivalents of dibromobenzene and only $4 \mathrm{~mol} \% \mathrm{Pd}$ (entry 9): monocyclen compounds 8 and 9 were isolated in $12 \%$ and $3 \%$ yields while bismacrocycle $\mathbf{1 0}$ was obtained in $30 \%$ yield.

It is difficult to explain reliably why the results of the reactions were obviously opposite to the stoichiometric ratios of starting compounds. We may suppose that the excess of trimethylcyclam or cyclen leads to a better complexation of palladium thus removing it from the catalytic cycle and diminishing the yield of bismacrocyclic products 7 and $\mathbf{1 0}$, the formation of which needs more palladium, than the synthesis of monocyclam(cyclen) derivatives 5, 6, 8, 9. However, it does not explain why diamination readily occures in the presence of excess dibromobenzene. Possibly the reason for such unprecedented fact is a favorable coordination of palladium by $N$-(3-bromophenyl)trimethylcyclam 6 and $\mathrm{N}$-(3-bromophenyl)trimethylcyclen $\mathbf{8}$, which stimulates the amination of the second bromine atom. However it may be, this effect has been never observed in the synthesis of $N, N$ 'bis(haloaryl)substituted linear polyamines in our previous research. To find the limits of the effect observed, we studied Pd-catalyzed arylation of tetraazamacrocycles $\mathbf{1}$ and 4 with various dihaloarenes like 2,7-dibromonaphthalene, 3,3'-dibromobiphenyl, 1,8-dichloroanthracene using various catalytic systems. Unfortunately, in all these cases the reactions gave complex inseparable mixtures which could not be analyzed.

\section{Conclusions}

To sum up, we synthesized biscyclam and biscyclen derivatives of 1,3-disubstituted benzene, showed an unusual dependence of the yields of these products on the stoichiometric ratio of starting compounds. We demonstrated better efficacy of DavePHOS in the diamination process compared to BINAP and found out conditions for the monoamination of 1,3-dibromobenzene with trimethylcyclam and trimethylcyclen.

Acknowledgements. The work was supported by the RFBR grants N 08-03-00628, 09-03-00735 and by the Russian Academy of Sciences program "Elaboration of the methods for the synthesis of chemical compounds and construction of new materials". Authors are indebted to CHEMATECH Co and personally Dr. F. Boschetti for a generous supply with cyclam and $N$-benzylcyclen.

\section{References}

1. Meyer M., Dahaoui-Gindrey V., Lecomte C., Guilard R. Coord. Chem. Rev. 1998, 180, 1313-1405.

2. Lukes I., Kotek J., Vojtisek P., Hermann P. Coord. Chem. Rev. 2001, 216, 287-312.

3. Barbette F., Rascalou F., Chollet H, Babouhot J.L., Denat F., Guilard R. Anal. Chim. Acta 2004, 502, 179-187.

4. Cuenot F., Meyer M., Bucaille A., Guilard R. J. Mol. Liq. 2005, 118, 89-99.

5. Gunnlaugsson T., Leonard J.P. Chem. Commun. 2005, 31143131.

6. Gunnlaugsson T., Stomeo F. Org. Biomol. Chem. 2007, 5, 19992009.

7. Reichenbach-Klinke R., König B. J. Chem. Soc., Dalton Trans. 2002, 121-130.

8. Aoki S., Kimura E. Chem. Rev. 2004, 104, 769-787.

9. Ritter S. C., Eiblmaier M., Michlova V., König B. Tetrahedron 2005, 61, 5241-5251.

10. Liu S., Edwards D.S. Bioconj. Chem. 2001, 12, 7-34.

11. Delgado R., Felix V., Lima L.M.P., Price D. W. Dalton Trans. 2007, 2734-2745.

12. Brandès S., Gros C., Denat F., Pullumbi P., Guilard R Bull. Soc. Chim. Fr. 1996, 133, 65-73.

13. Valks G.C., McRobbie G., Lewis E.A., Hubin T.J., Hunter T.M., Sadler P.J., Pannecouque C., De Clercq E., Archibald S.J. J. Med. Chem. 2006, 49, 6162-6165.

14. Bradshaw J.S., Krakowiak K.E., Izatt R.M. Aza-Crown Macrocycles New York: Wiley, 1993, 51. 
15. Lindoy L.F. The Chemistry of Macrocyclic Ligand Complexes Cambridge: Cambridge University Press 1989, 122.

16. Schneider R., Riesen A., Kaden T.A. Helv. Chim. Acta 1985, 68, 53-61.

17. Ciampolini M., Fabbrizzi L., Perotti A., Poggi A., Seghi B., Zanobini F. Inorg. Chem. 1987, 26, 3527-3533.

18. Urfer A., Kaden T.A. Helv. Chim. Acta 1994, 77, 23-35.

19. Bridger G.J., Skerlj R.T., Thornton D., Padmanabhan S., Martellucci S.A., Henson G.W., Abrams M.J., Yamamoto N., De Vreese K., Pauwels R., De Clercq E. J. Med. Chem. 1995, 38, 366-378.

20. Buttafava A., Fabbrizzi L., Perotti A., Seghi B. J. Chem. Soc. Chem. Commun., 1982, 1166-1167.

21. Fabbrizzi L., Montagna L., Poggi A., Kaden T. A., Siegfried L. C. Inorg. Chem. 1986, 25, 2672-2674.

22. Buttafava A., Fabbrizzi L., Perotti A., Poggi A., Seghi B. Inorg.
Chem. 1984, 23, 3917-3922.

23. Kajiwara T., Yamaguchi T., Kido H., Kawabata S., Kuroda R., Ito T. Inorg. Chem. 1993, 32, 4990-4991.

24. Beletskaya I. P., Averin A. D., Bessmertnykh A. G., Denat F., Guilard R. Tetrahedron Lett. 2002, 43, 1193-1196.

25. Ukai T., Kawazura H., Ishii Y., Bonnet J.J., Ibers J.A. J. Organomet. Chem. 1974, 65, 253-266.

26. Guilard R., Denat F., Pernelet O., Tripier R., Ledon H., Devos C. FR 2789380, 2000.

27. Pilichowski J. F., Lehn J.-M., Savage J.-P., Gramain J.C. Tetrahedron 1985, 41, 1959-1964.

28. Wolfe J. P., Buchwald S.L. J. Org. Chem. 2000, 65, 1147-1157.

29. Averin A.D., Shukhaev A.V., Golub S.L., Buryak A.K., Beletskaya I.P. Synthesis 2007, 2995-3012.

30. Wolfe J.P., Tomori H., Sadighi J.P., Yin J., Buchwald S.L. J. Org. Chem. 2000, 65, 1158-1174. 